\title{
DECISION RULES, DECISION STYLES AND POLICY CHOICES
}

\author{
Fritz W. Scharpf
}

\begin{abstract}
The article emphasizes the importance of theory construction for comparative policy research. Attempts to identify the impact of institutional arrangements on policy choices are complicated by interaction effects between institutionalized boundary and decision rules on the one hand, and 'decision styles' on the other hand - which are defined as cognitive and normative patterns that characterize the way in which interests are defined and issues framed and resolved under the applicable rules. A typology of such styles is developed with reference to recent findings of experimental social psychology, and the empirical implications of different combinations of decision rules and decision styles are examined in a game-theoretical context.
\end{abstract}

KEY WORDS • institutions $\bullet$ decision rules $\bullet$ decision styles $\bullet$ game theory

\section{Introduction}

Much of comparative political science research may be characterized as an attempt to explain and predict the influence of political institutions on the choice of public policy. ${ }^{1}$ Yet there is, so far, no cumulative progress toward a body of coherent, empirically supported general theory, or even toward agreement on a common set of independent and dependent variables and testable hypotheses (Feick and Jann, 1988). By now, that state of affairs can, surely, no longer be attributed to a scarcity of comparative policy studies, as one might still have surmised twenty-five years ago (Lowi, 1964). Instead, the difficulties seem to arise from the highly contingent nature of the postulated relationship itself, and they are likely to persist unless research is able to deal effectively with this problem.

But what are the sources of contingency in the relationship between political institutions and policy choices? When we consider the formation of public policy (as distinguished from its implementation) we may assume that institutions - a shorthand term for organizational capabilities and the rules governing their employment - will constrain, but not completely determine, policy choices. Nevertheless, certain policy options will be empirically infeasible, or at least severely disadvantaged by the absence of requisite capabilities, and others

1. Even more ambitiously, political scientists often try to link institutional differences directly to policy outcomes, such as inflation or unemployment or mortality rates, in quantitative cross-national comparisons. Such associations are likely to be unstable, however, unless explanatory models also include valid (multi-disciplinary) specifications for the causal linkages between characteristics of policy environments, policy output, and outcomes. 
will be normatively prohibited by given sets of effective rules. In short: certain policy options are unlikely to be chosen under certain institutional conditions. ${ }^{2}$

How much such negative predictions would be worth in practical (or information theoretical) terms, depends on the relative importance of the choices that are precluded by given institutional constraints, compared to those that are not. Ordinarily, however, the range of feasible and permissible options is so wide that institutional hypotheses alone could at best explain only a small portion of the empirical variance of policy outputs (and still much less of the variance of policy outcomes). The rest must be explained by a considerable variety of 'contextual factors', including differing conditions of the policy environment, differing interests and goals of policy-makers and differing belief systems ${ }^{3}$ through which policy-makers are interpreting cause-and-effect and means-end relationships. Thus, policy choices are simultaneously influenced by at least four sets of factors, institutional, situational, preferential and perceptional, rather than by institutional constraints alone.

Now it is true that the presence of additional variables need not discourage institutional analyses of policy choices - as long as we could still be sure that they are in fact explaining some part of the empirical variance. But even that assumption is thrown into doubt by the prevailing methodology of comparative policy research, which uses statistical methods for the discovery, as well as for the confirmation, of empirical regularities. If we have theoretical reasons to think that an outcome is influenced by several factors, these are high-risk strategies. Bivariate analyses concentrating upon a single independent variable, or multivariate analyses that use only a few variables, may produce spurious correlations that would disappear with the introduction of additional factors (Blalock, 1961). Yet the number of variables that are theoretically relevant in an explanation of policy choices is so large that we are likely to run out of cases (even in 'pooled time series analyses') whenever we try to run multivariate analyses for the complete set. ${ }^{4}$ As a consequence, quantitative cross-national policy studies are often limited to very small subsets of an unknown universe of potentially relevant explanatory factors. Different studies are likely to focus upon different subsets, and even when they use the same set of variables, their findings are likely to be unstable if uncontrolled background factors should

2. The matter is complicated further by equifinality and institutional learning. If environmental conditions requiring specific solutions persist long enough, countries in comparable situations are likely to come up with functionally equivalent policy responses regardless of institutional differences.

3. 'Keynesian' and 'monetarist' policy-makers, for instance, did draw quite different policy conclusions from the changes in the world economic environment in the 1970s (Scharpf, 1987).

4. If we try to increase the number of cases by going beyond the 15 or so OECD countries which are generally considered 'comparable', we also introduce additional dimensions of empirical variation which add to the number of variables that need to be controlled. 
differ from one study to another. In short: there is no reason to expect convergence when cross-national studies ae used to discover (rather than to test) theory.

Comparativists who are aware of these difficulties sometimes try to reduce the number of relevant variables by self-consciously applying the 'most similar systems design' (Przeworski and Teune, 1970) to their selection of cases. It may be possible, for instance, to hold constant much of the environmental, preferential and perceptional variance if we focus on a standardized set of severe and obvious policy problems - in the hope that these 'single exit' conditions (Latsis, 1972; Zintl, 1987) will also have concentrated the minds of political actors upon convergent goals and hypotheses. Additionally, analyses may be limited to subsets of policy-makers with common interests and ideological orientations and, presumably, shared goals and perceptions. When these assumptions are approximately correct, it is indeed more plausible that the remaining differences in policy choices might in fact be due to differences in institutional constraints.

But we must realize that these are limited solutions. Single-exit assumptions often founder on the realities of ideological conflict and historical change, and the search for ideologically homogeneous preferences and perceptions will often end up with so few cases that the remaining situational and institutional differences will again confound comparative explanations. Thus the conclusion seems inevitable that neither cross-national quantitative studies nor the 'discovery of grounded theory' (Glaser and Strauss, 1967) in matched case studies will generally be able to cope with the range of contingent linkages between political institutions and policy choices.

That does not mean that we should abandon the hope of developing and validating general theory in the field of comparative policy research. But the less we are able to trust the generality of our empirical findings, the more urgently we need to improve the trustworthiness of the theoretical models that we are submitting to empirical tests. To do so, we need to complement the inductive discovery of grounded theory with a significant investment in the construction of theoretical models with a higher degree of internal plausibility, and external compatibility with pre-existing empirical and theoretical knowledge (Willer, 1978; John, 1980; Layder, 1982). These must necessarily consist of relatively narrow but well-understood 'partial theories' that can be combined, in historically specific configurations, in more complex explanations of real-world phenomena. While axiomatic theorizing cannot, by itself, produce knowledge about the real world, it may sharpen the expectations that guide our search for, and help us to make better use of, the evidence that is available. In that spirit, the present article will try to develop some abstract and partial propositions about the range of possible linkages between political institutions and policy choices. 


\section{Boundary Rules, Decision Rules and Policy Choices}

In more abstract models it is of course no longer possible to use the concrete dependent variables of empirical research - i.e. specific policy choices evaluated by the goals of given policy-makers. They need to be replaced by more abstract descriptors of the quality of policy choices. At the most general level, these may be defined along three dimensions of a social welfare function: interpersonal, intertemporal, and substantive.

1. In the interpersonal (or inter-group) dimension, the criterion is inclusiveness: to what extent will different institutional arrangements extend or reduce the range of interests that are taken into account in policy choices? Do they tend to emphasize the defense of narrowly defined particular interests, or the pursuit of broadly defined collective interests?

2. In the intertemporal dimension, the criterion is stability: to what extent are institutional conditions conducive to policy choices that are able to stand the test of time - in the sense that they will reflect not momentary impulses or short-term interests but - in the words of one of the great justices of the United States Supreme Court - 'the sober second thought' of the community (Stone, 1936: 25; Bickel, 1962: 23-8)?

3 . In the substantive dimension, finally, the criterion is social optimality: to what extent will institutions favor policy choices that are able to eliminate Pareto-inferior solutions by avoiding unnecessary welfare losses, and by exploiting opportunities for increasing total social welfare?

But how could institutional arrangements affect the interpersonal, intertemporal and substantive quality of policy choices? Institutions, it will be remembered, are here defined as configurations of organizational capabilities (assemblies of personal, material and informational resources that can be used for collective action) and of sets of rules or normative constraints structuring the interaction of participants in their deployment. Thus institutions create the power to achieve purposes that would be unreachable in their absence (Thompson, 1970). However, the power to achieve collective purposes is also the power to destroy, to oppress, to exploit, and to command. It is likely to be resisted unless its exercise is supported by norms assuring compliance and they in turn cannot be effective without rules specifying conditions and limits for the exercise of organized power. Among these rules, ${ }^{5}$ two will receive special consideration here as particularly powerful predictors of policy choices: 'boundary rules' defining the units of collective action, and 'decision rules' governing the transformation of preferences into binding decisions.

5. In a recent paper defining the agenda for institutional analysis. Elinor Ostrom (1986a: 468-71) distinguished among seven types of rules, all of which may shape the choice of public policy. Her list includes 'boundary rules', 'scope rules', 'position rules', 'authority rules', 'information rules', 'aggregation rules', and 'payoff rules'. Of these, 'boundary rules' define 'the entry, exit and domain conditions for individual participants', while 'aggregation rules' (for which I have chosen the term 'decision rules') are employed for 'weighing individual choices and calculating collective choices at decision nodes'. 
Within a policy context, boundary rules are important at two levels: they define collective identities, and they also define units within which 'governance' replaces 'contracting' as a procedure for reaching jointly binding decisions.

At the first level, identities define the reference systems by which policy choices are evaluated. Even within the confines of methodological individualism, it must be conceded that individuals are capable of developing 'we identities' at various levels of identification (Elias, 1987: 269-74) - the family, the clique, the firm, the local community, the labor union, the nation-state. Any one of these collective identities may, at one time or another, become the effective referent for the comparison of alternative courses of action. Whenever that is true, individual action can only be explained and predicted by reference to the utility of the relevant collective unit whose membership is circumscribed by boundary rules.

At the second level, collective units are characterized by governance as an institutionalized capacity for purposeful action which rests ultimately on the power of the group or organization (or of its representatives) to appropriate and commit resources and capabilities of members without their present consent. Who is bound by such decisions is, of course, again determined by boundary rules. ${ }^{6}$ Collective units with this capacity for governance may be treated as 'corporate actors' in their own right (Coleman, 1974).

The power of governance, however, will not reach very far unless it is based on widely accepted decision rules that specify who is entitled to participate in which decisions, and how collective choices are to be reached in the face of disagreement among legitimate participants. At the most general level, these decision rules may specify hierarchical, majoritarian, or unanimous procedures for conflict resolution. Hierarchy implies the unilateral power of one participant (or of a few participants) to determine the choices of all others, Majority invests the numerically larger faction with the same power, and Unanimity makes governance dependent upon the agreement of all.

As a consequence, institutionalized boundary rules unite and separate. They unite individuals (or rather, role segments of individuals) who share a certain collective identity, and they separate them from others whose identity is recognized as being different. More important, they unite individuals among whom coordination may be imposed through intra-unit governance, and they separate them from others with whom purposeful coordination ${ }^{7}$ is

6. Ideally, the units defined by boundary rules at both these levels would coincide. In practice, that is not necessarily so: the reference system of decision-makers may be narrower or more inclusive than the collectivity over which governance is exercised, or the two may even be disjoint (as in the case of a military occupation).

7. That leaves out two other important modes of coordination, social norms and 'spontaneous field control' (Dahl and Lindblom, 1953: 99-104), or 'ecological coordination', achieved through unilateral adaptation to an environment constituted by other actors. 


\section{only achieved through contracting. ${ }^{8}$}

Yet as important as the distinction between governance and contracting may be, it is not as clearly dichotomous as it might seem. One theoretical bridge between the extremes is provided by the 'Coase Theorem' (Coase, 1960) which demonstrates that in the absence of transaction costs all coordinative and regulatory functions of government could also be achieved by contract - albeit with different distributive consequences. The underlying assumption about transaction costs has since given rise to an economic theory of organization which, at first, has drawn a sharp dividing line between 'hierarchical' and 'market' forms of coordination (Williamson, 1975). In the meantime, lawyers and sociologists have (re)discovered a variety of more stable and encompassing or socially embedded 'relational' or 'hierarchical' contract relations (Macneil, 1978, 1983; Dore, 1983; Stinchcombe, 1985; Powell, 1987) which are far removed from the 'spot contracts' among perfect strangers that were presumed to be characteristic of the 'market' end of the dichotomy. As a consequence, transaction cost economics now also recognizes intermediate types of coordination that fall between the extreme forms of pure markets and pure hierarchies (Williamson, 1979, 1985). Thus, the categorical difference between inter-unit 'contracting' and intra-unit 'governance', tends to become a matter of degree when relational contracts are included on the one side, ${ }^{9}$ and governance by unanimous agreement is allowed on the other side. ${ }^{10}$ Recognition of this fact may help us to achieve a more cumulative social science in which economists have much to learn from studying so-called public institutions, and political scientists from studying the interactions among so-called private organizations.

8. As Ian Macneil (1987) has emphasized, the difference is not the presence or absence of compulsion, since contracts are also based on power - defined by the relative dependence of parties on the goods or services offered by the other side. What matters is whether choice is exercised individually (or by each unit separately) or collectively - whether I decide for myself, or whether decisions are made for me (with or without my participation).

9. In the literature, a further distinction is introduced between 'classical contracts' conforming to our description of 'spot' contracts and 'neoclassical contracts' referring to longer-term relationships with provisions for adjusting to uncertain future events which are, however, less elaborate than those associated with 'relational contracts' (Williamson, 1979). This further emphasizes the continuity among the various forms of coordination.

10. Thus the more important distinction might be drawn between interactions from which low-cost exit is possible, and 'ongoing' interaction systems without exit. But again, that distinction becomes a matter of degree when the 'embeddedness' of spot contracts, and the potential exit from tightly integrated organizations, are considered.

11. Conventionally, decision rules may be attributed to different decision arenas in the following way:

\begin{tabular}{ll}
\hline Arena & Decision rules \\
\hline Within public-sector organizations & Hierarchy, Majority \\
Between public-sector organizations & Hierarchy, Unanimity \\
Between public and private sector & Hierarchy, Unanimity \\
Within private-sector organizations & Hierarchy, Majority \\
Between private-sector organizations & Unanimity \\
\hline
\end{tabular}




\section{The Importance of Negotiating Systems}

But what is the practical importance of this middle ground for the analysis of public policy choices? When we consider only formal decision rules, ${ }^{11}$ we might get the impression that hierarchical and majoritarian forms of governance predominate so completely in the public sector that governance by unanimous agreement should be considered as an empirically rare and exotic exception that merits theoretical attention only as a limiting case. Yet Gerhard Lehmbruch and Arendt Lijphart have directed our attention to the importance of de facto unanimity among competing political camps in the 'consociational democracies' of some small European countries that are, of course, formally governed by majority (Lehmbruch, 1967, 1968, 1979; Lijphart, 1969). Similarly, Philippe Schmitter's $(1979,1981)$ 'neocorporatist' patterns of interest intermediation also imply the consensual settlement of issues which are formally subject to the exercise of hierarchical government authority. In the same vein, Renate Mayntz found negotiated settlements to be characteristic features of the implementation of environmental regulations even though the relationship between government agencies and private firms is clearly hierarchical in a legal sense (Mayntz et al., 1978). In our own studies of federal state relations in Germany, we also observed a practice of unanimous agreement even in policy areas where majority decisions, or even unilateral decisions by the federal government, are formally prescribed (Scharpf et al., 1978; Garlichs, 1980; Reh, 1986; Posse, 1986). Similarly, Shepsle and Weingast (1981; Weingast, 1979) have found a tendency toward unanimous decisions (rather than the 'minimum winning coalitions' predicted by public choice theory) in the committees of the US Congress operating under simple majority rules. The list could easily be extended to other institutional contexts. In short: recent studies of decision-making in the public sector seem to emphasize the practical need for consensus and the importance of unanimity even in situations where formal decision rules would permit, or even require, either unilateral/hierarchical or majority decisions. ${ }^{12}$

In the private sector, on the other hand, Hierarchy is assumed to be the decision rule within organizations, while contracts based upon unanimous agreement are the only legitimate means of coordination between private sector organizations. Nevertheless, relational or hierarchical contracts may include explicit arrangements for unforeseen contingencies that approximate governance systems in the sense that certain decisions (e.g. by an arbitrator) are accepted despite continuing disagreement. Of even greater practical importance may be the embeddedness of a great variety of formally sepa-

12. This is not to suggest that the distinction between de facto and formal decision rules should be unimportant. Consensual decision systems operating 'in the shadow' of formal Hierarchy or Majority rules are on the whole less likely to be exploited by recalcitrant dissenters than decision systems operating under formal Unanimity. But if de facto rules have achieved legitimacy, the practical difference may not be very great (Scharpf, 1988c). 
rate contracts in longer-term and more encompassing relations among the parties. As a consequence, the costs of exit from such relationships may increase to the point where they will in fact approach 'the properties of a minisociety' (Williamson, 1979: 238) whose requirements are respected even if they are disliked. Among the most prominent examples are the 'clans' of cooperating firms in Japanese industry (Ouchi, 1980, 1984) or the stable networks of suppliers and customers that are characteristic of 'just-in-time' production or of 'flexible specialization' in some European regional economies (Piore and Sabel, 1984; Sabel, 1987). For all we know, many varieties of more common contractual relations may also have similar characteristics.

To summarize: between the extreme types of purposeful coordination, defined by 'markets' (spot contracts) and 'hierarchies', there exists a broad middle ground of consensual negotiation systems within and between organizations (Figure 1). Their practical importance seems to be considerable, and is probably increasing, in the public as well as in the private sector.

Figure 1. Typology of coordination mechanisms

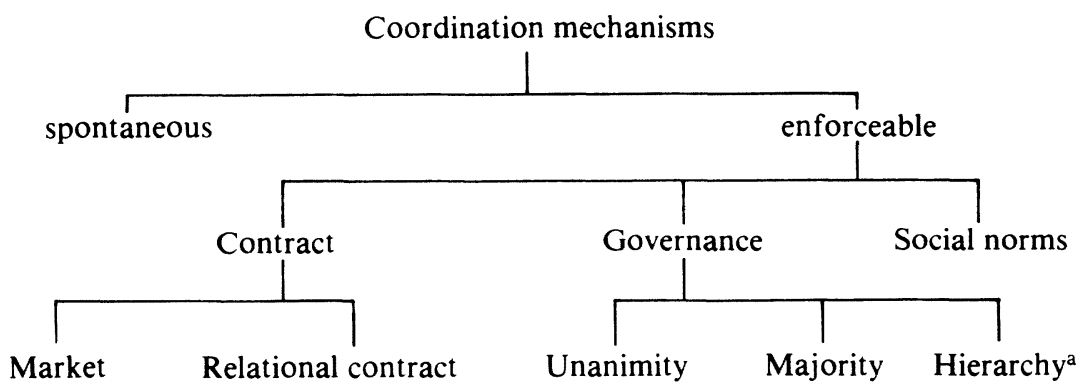

${ }^{a}$ At a next level, one might distinguish among different forms of hierarchies, depending upon whether they are based merely on a preponderance of power, or are supported by 'traditional', 'democratic' or 'contractual' forms of legitimation.

Unfortunately, however, the policy implications of such negotiating systems are theoretically much less well understood than those of either pure markets or clearcut hierarchical or majoritarian decision systems. Leaving pure markets aside, it is nevertheless possible to develop some preliminary hypotheses about the likely consequences of consensual, majoritarian and hierarchical forms of coordination for the interpersonal inclusiveness, intertemporal stability, and substantive optimality of policy choices.

\section{Policy Implications of Decision Rules}

To begin with the criterion of interpersonal inclusiveness, all decision systems are likely to favor the interests of their members over those of outsiders which once more emphasizes the importance of boundary rules. Whether decision rules will make much of a difference in that regard is more uncertain 
- except that systems operating under unanimity may find generosity particularly difficult to achieve since unselfish decisions can be blocked by the veto of a single egotist. The case is clearer when we consider issues of internal distribution among members. As is recognized in the Coase Theorem itself, the potential for redistribution is reduced as one moves from governance to contract and from hierarchical to unanimous decisions. While hierarchical authorities or hegemonic powers are free to disregard any interests and to choose any distributive rule, ${ }^{13}$ and while majoritarian decisions may at least disregard minority interests, ${ }^{14}$ unanimity eliminates the possibility of involuntary redistribution. That does not exclude unequal contractual exchanges - but these are derived from a pre-existing inequality of bargaining positions (i.e. of the relative attractiveness of alternative options when the bargain is not concluded), rather than from the decision process itself (Nash, 1950, 1953; Bacharach and Lawler, 1981). Thus, consensual decision rules permit each party to defend the existing pattern of distribution, while Majority and Hierarchy create at least the opportunity for involuntary redistribution (which may, of course, increase as well as decrease existing inequality).

With regard to the intertemporal stability of policy choices, hierarchical decision systems have perhaps the greatest freedom to consider long-term as well as short-term concerns (but see note 13), and majoritarian parliamentary systems may tend to maximize short-term benefits when elections are frequent and pluralities uncertain. By comparison, the implications of Unanimity seem more uncertain: freed from (some of) the pressure of party competition and more secure in their expectations of continuing participation, decision-makers are less compelled to maximize short-term advantages. But given the high transaction costs associated with Unanimity, effective policy choices will often depend on complexity-reducing and conflict-avoiding redefinitions of the problem at hand (Scharpf et al., 1978) - and limiting discussion to incremental changes and their short-term consequences is surely one of the most common techniques for reducing complexity (Braybrooke and Lindblom, 1963).

Finally, with regard to substantive criteria of allocative efficiency or optimality, Unanimity is favored in principle (i.e. in the absence of transaction costs) by public-choice theorists (Buchanan and Tullock, 1962: 85-96). Precisely because the rule excludes involuntary redistribution, agreement can only be obtained for policy choices through which nobody loses and some are made better off, or through which the winners are able to compensate

13. If Hierarchy needs to be legitimated, the source of legitimacy (traditional, contractual, or democratic) will significantly affect its freedom of choice. Of particular interest is the case of democratic legitimation through electoral competition among elites. If elections are frequent and competition is intense, hierarchical decisions may be systematically biased toward the most egotistic, myopic and narrowly defined interests of constituents. Lyndon Johnson put it all in a nutshell with his quip that 'You got to be re-elected to be a statesman' - and it is no wonder that the 'statesmen' in the US Congress often come from one-party constituencies.

14. That presumes the existence of stable majority coalitions. If coalitions are unstable, redistribution may be impossible even under the majority rule, as the losers of the last round will always be able to bribe some members of the former majority to switch sides (Mueller, 1979: 220). 
the losers and still make a gain. When that is so, the trend of decisions will approach the frontier of Pareto optimality. Under the additional assumption that the original distribution is normatively acceptable, Unanimity will then be the ideal rule, compared to which majority decisions are likely to produce inferior outcomes - even though transaction costs may make them a practical necessity.

However, as I have tried to show elsewhere (Scharpf, 1988c), the normative attractiveness of Unanimity is critically dependent upon what Elinor Ostrom (1986b) has called the 'default condition' or 'reversion rule' that specifies the consequences of non-agreement. In single-shot negotiations among independent parties, non-agreement leaves everybody free to pursue their alternative options individually. Under such conditions, Unanimity is indeed likely to maximize individual liberty and to increase allocative efficiency. In ongoing decision systems, by contrast, from which exit is impossible or very expensive, non-agreement is more likely to imply the continuation of earlier policy choices. ${ }^{15}$ Where that is the case, Unanimity protects vested interests in existing regulations and government services, regardless of any changes in external circumstances or political preferences that would preclude contemporary agreement on these same measures. Thus, once we move from single-shot decisions to ongoing decision systems, there is no reason to associate either efficiency or libertarian values with Unanimity or with contractarian institutions: They will perpetuate 'involuntary' governance and socially inefficient 'political rents' by protecting the past gains of 'distributional coalitions' (Olson, 1982) against policy change. Thus, in ongoing decision systems and under conventional assumptions about the motives of decision-makers, Unanimity is likely to be associated with a growing body of public policies that are illibertarian and substantively inferior to those that might have been obtained under hierarchical or majority decision rules.

This is about as far as it seems possible to discuss the policy consequences of different decision rules in the abstract, and in advance of further empirical work. Yet these are, at best, ceteris paribus hypotheses that must necessarily leave a very large amount of variance unexplained. Thus any attempt to 'test' them in comparative empirical research is likely to be confounded by the fact that institutions with similar decision rules will work differently in different countries and at different times, and that similar policy patterns may be produced within highly dissimilar institutional arrangements. The difficulty would be most acute if all of the additional determinants of policy choices were highly idiosyncratic, time-space specific contextual factors that could only be accounted for in 'historical explanations' of very limited generality.

15. Dennis Mueller (1979: 214) comes close to recognizing the problem when he mentions that the unanimous adoption of one proposal on the Pareto frontier will henceforth prevent the adoption of all other proposals from the Pareto-efficient set. What is added here is the possibility that the earlier choice is moved away from the frontier, not by another collective decision but, by changing circumstances or preferences. 'Sunset legislation' could not eliminate this problem since it would violate those interests that are better off under the existing statute. 
Conversely, the difficulties of theory-testing would be reduced if it were possible to develop additional hypotheses of similar generality about other factors interacting with the influence of institutional decision rules. In the remainder of this article, I will focus on one such set of factors which seems to modify the decisional tendencies associated with different rules.

\section{Styles of Decision-making}

The reference is to a set of cognitive and normative patterns characterizing the way in which interests are defined and issues framed and resolved under the applicable rules. To characterize such patterns, I have used the term 'styles of decision-making' in an earlier paper (Scharpf, 1988c). In spite of considerable differences in terminology, I have also found a high degree of substantive convergence on three distinct categories in the literature. 16 Taking my terminological cues from Johan Olsen and colleagues (1982), I have used 'Confrontation', 'Bargaining', and 'Problem-solving' for my own classification of decision styles.

Confrontation refers to competitive interactions in which winning, or the defeat of the other side, has become the paramount goal, and in which the battle can typically be decided only by superior prowess or force. In a Bargaining relationship, by contrast, individualistic participants are unconcerned about the relative advantage of the other side, and exclusively motivated by their own utilitarian self-interest. The typical outcome is a compromise. Problem-solving, finally, implies the pursuit of common goals and the cooperative search for solutions that are optimal for the group as a whole. While the intended meanings of all three categories may be intuitively obvious, it seems useful to provide more rigorous definitions for them through the application of game theoretic analyses. To do so requires a brief look at the fundamentals.

When discussing factors that may affect the definition of interests and the framing of issues, one must necessarily presuppose a certain degree

16. A close reading reveals a surprising degree of convergence between seemingly unrelated conceptualizations. Mary Parker Follet (1941), for instance, had discussed the resolution of industrial conflict through 'domination', 'compromise', or 'integration', while Russell Hardin (1982) uses 'conflict', 'contract' and 'coordination' as descriptors for different forms of collective action. At the organizational level, Amitai Etzioni (1961) seems to refer to similar variables in his distinction between 'coercive', 'utilitarian', and 'normative' commitments and controls; and the same seems to be true, at the level of political systems, of Thomas Bonoma's (1976) characterization of 'unilateral', 'mixed' and 'bilateral' power systems. Of course, not all pertinent conceptualizations in the literature come in triads. March and Simon (1958: 129-31) suggest four categories - 'problem solving', 'persuasion', 'bargaining' and 'politics' (of which the first two are collapsed here). Walton and McKersey (1965) limit their discussion to 'distributive' and 'integrative bargaining', while Midgaard (1983) discusses 'tug-of-war' and 'cooperative bargaining', both corresponding to Bargaining and Problem-solving in the terminology proposed here. The same correspondence exists with the notions of 'negative' and 'positive coordination' between ministerial departments (Scharpf, 1972; Mayntz and Scharpf, 1975: 145-50). 
of loose coupling between objective reality and the perception of interests. This departure from parsimonious rational-choice assumptions would not be useful if real-world interactions were often of the kind presumed by the dichotomy between 'symbiotic' and 'competitive' relationships. In both cases, misperceptions of the 'objective' game situation (pure coordination or pure zero-sum) by rational actors would be too idiosyncratic and infrequent to justify much theoretical or practical interest. In the real world, however, purely competitive or purely symbiotic interest constellations are extremely rare, and probably unstable, compared to 'mixed-motive' constellations in which the parties have common as well as competitive interests at the same time. ${ }^{17}$ It is their objective ambivalence, pulling participants simultaneously toward cooperation and toward conflict, which also creates room for the redefinition of the interests and issues at stake. Thus, in the game-theoretical literature, much attention is focussed on four prototypical mixed-motive games, 'Assurance', 'Prisoner's Dilemma', 'Chicken', and 'Battle of the Sexes' (Figure 2). ${ }^{18}$

Figure 2. Payoff matrices of four mixed-motive games ${ }^{a}$

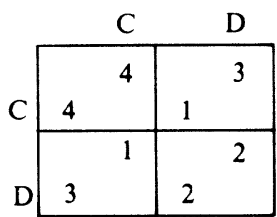

Assurance

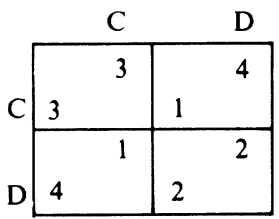

Prisoner's Dilemma

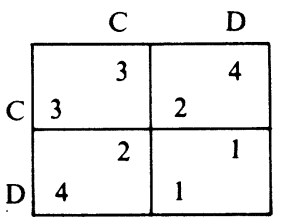

Chicken

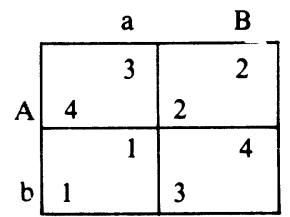

Battle of Sexes

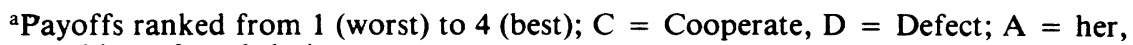
$\mathrm{B}=$ his preferred choice.

By and large, however, the discussion is concentrated on 'non-cooperative' solutions obtainable without the possibility for binding agreements. Within that frame of reference, the application of conventional solution concepts to

17. The game of pure coordination will turn into the mixed-motive 'Assurance Game' if there is any uncertainty about the other party's understanding of the interest constellation; it may be transformed into a 'Prisoner's Dilemma' if there is suspicion of free-riding; or it may assume the character of 'Battle of the Sexes' if the distribution of the costs and benefits of joint action becomes an issue. Conversely, pure competition will be transformed into the mixed-motive game of 'Chicken' if the common interest in avoiding mutual destruction is realized by the participants.

18. While the 'Prisoner's Dilemma' and 'Chicken' are too well known to need introduction, 'Assurance' is best described by Jean Jacques Rousseau's tale of a band of savages on a stag hunt: If they all stay together, they will catch the big game and all will eat well. But if one of them defects to catch a rabbit, he alone will eat (though less well), while all others go hungry. 'Battle of the Sexes' (alias 'Hero') is usually illustrated by the couple who would like to spend an evening going out together, but she would prefer the opera and he a ball game. One might also think of a two-career academic couple having to choose among universities offering appointments that differ in their attractiveness for her and him. 
these four games ${ }^{19}$ will lead either to equilibria which are suboptimal for both parties or to outcomes which are unstable. ${ }^{20}$ Yet the emphasis which these famous 'paradoxes of rationality' have received in the literature may be quite misleading for the analysis of public policy formation.

Policy processes take place within the institutional context of an established 'state' that provides for the possibility of binding contracts and of binding governmental decisions, and policy choices are usually (though not invariably) binding not only for their target populations, but for policy-makers as well. That is generally true of negotiated settlements among public entities as weli as between public and private organizations and in collective bargaining among private associations. But even under hierarchical or majoritarian decision rules, courts are bound by the rule of res iudicata, and sovereign parliamentary majorities might face electoral sanctions if they should lightly rescind their own enactments. In short: the impossibility of binding commitments, assumed in analyses of non-cooperative games, is typically not to be presupposed in real-world policy processes.

But when the assumption is relaxed, the choice of a negotiated solution becomes a trivial problem in three of the four prototypical mixed-motive games. ${ }^{21}$ In Assurance as well as in the Prisoner's Dilemma and in Chicken, it is obvious that voluntary agreement could never be obtained for those outcomes in which the cooperation of one party is exploited by the defection of the other one $(\mathrm{D} / \mathrm{C}$ or $\mathrm{C} / \mathrm{D})$. But once the possibility of exploitation is eliminated, there is no doubt that both parties will prefer the outcome obtained by mutual cooperation $(\mathrm{C} / \mathrm{C})$ over that which is expected in the case of mutual defection (D/D). In each of these three cases, therefore, cooperative solutions seem entirely unproblematic if binding agreements are possible. ${ }^{22}$ The same is not true, however, in Battle of the Sexes. While it is clear that both would prefer one of the coordinated outcomes $(\mathrm{A} / \mathrm{a}$ or $\mathrm{B} / \mathrm{b})$ over the possibility of each going her/his own way $(\mathrm{A} / \mathrm{B})$, that is by no means the end of their difficulties, since they must still choose between two solutions whose distributional characteristics are significantly different from

19. In empirical research it is, of course, necessary to reconstruct the payoff matrices of the games which are in fact played by the parties. They need not resemble any one of these archetypical game constellations, and they are unlikely to be symmetrical. Nevertheless, these four games are suggestive of important types of real-world relationships.

20. In the Assurance Game (assuming that the parties are unable to trust each other's rationality) and in the Prisoner's Dilemma, the suboptimal equilibrium (D/D) is obtained if both parties apply the minimax rule. In Chicken, the minimax rule would produce a cooperative outcome $(\mathrm{C} / \mathrm{C})$ which, however, is not a game-theoretical equilibrium. In Battle, minimax strategies would lead to a suboptimal outcome (A/B) which is also unstable.

21. The same is, of course, true of all imposed solutions, i.e. when one party is able to determine the outcome under hierarchical or majoritarian decision rules. I will return to that point in the concluding section.

22. Andreas Ryll has pointed out to me that this is necessarily true only in situations which are plausibly represented as a two-person game. When the number of players increases, the collective optimum may no longer be unique, and the difficulties of choosing among multiple optima with differing distributive characteristics may be similar to those encountered in Battle (Sen, 1969: $12-15)$. 
each other. If the Prisoner's Dilemma, Chicken and Assurance are modelling the problem of whether the parties are able to cooperate, Battle is about on whose terms they should agree.

Before we go further, it is important to note that the characteristics of Battle apply to an extremely wide range of real-life constellations. Not only intimate partners, but also business firms engaged in joint ventures, unions and management in collective bargaining, inter-ministerial (Mayntz and Scharpf, 1975), federal-state and inter-European policy coordination (Scharpf, 1988c) or political parties in a coalition (Tsebelis, 1988), and many similar joint undertakings, are all confronted with the same problem: while the benefits of cooperation are more attractive than the outcomes expected in the case of non-agreement, cooperation is seriously threatened by distributive conflict over the choice among cooperative solutions (or over the allocation of the costs and benefits of cooperation). It is probably fair to say that in the great majority of ongoing relationships that is the major obstacle to cooperative solutions.

In spite of its enormous practical significance, however, Battle of the Sexes has received much less attention in the game-theoretical literature than the Prisoner's Dilemma or Chicken games (Luce and Raiffa, 1957: 90-4; Hamburger, 1979: 128-30; Snidal, 1985: 931-2). That surely is related to the fact that, as a non-cooperative game, Battle is not theoretically interesting, since it does not have a unique and stable solution if conventional solution concepts are applied. ${ }^{23}$ As a consequence, interest has shifted from the positive analysis of expected outcomes to the discussion of 'fair' solutions in the context of pragmatic treatises on the 'art and science of negotiation' (Raiffa, 1982). From the vantage-point of empirical political science, however, that may not be the most promising line to pursue. Instead, it seems useful to apply to Battle some findings of experimental game research which have challenged another, even more generally held, assumption of game-theoretical analysis. These findings are directly pertinent to our interest in operational definitions of different styles of decision-making.

Game theory has started as a branch of economics (von Neumann and Morgenstern, 1944), and it has always maintained the motivational assumptions of microeconomic theory. Foremost among these is an individualistic 'live-and-let-live' definition of the utility which players are supposed to seek: All of them are single-mindedly maximizing their own expected utility with no concern for the payoffs received by other players (except as far as may be necessary to anticipate their moves). But that is, surely, not the full range of potential human motivations. Actors may be engaged in strategic interaction not only as strictly self-interested individuals, but also as competitors or even

23. Applying the minimax rule, the players would converge upon a suboptimal outcome (A/B) which (by contrast to the Prisoner's Dilemma) is not a game-theoretic equilibrium. Hence both players would like to leave that cell - but if they should do so without coordination, they will end up with their least preferred payoffs $(a / b)$. 
as mortal enemies, as partners in a common enterprise or even as participants in an altruistic helper-client relationship. None of these can be accommodated by the dominant economic paradigm. ${ }^{24}$

Social scientists and psychologists have, of course, long objected on similar grounds to the motivational simplifications of microeconomics without being able to replace or complement them with similarly powerful analytical tools. Thus we should be interested in a new conceptualization of such objections in a form which seems to facilitate, rather than to preclude, application of the analytical tools of game-theoretic and, more generally, rational-choice analyses to a wider range of social and political interactions. The conceptual innovation was achieved by Harold Kelley and John Thibaut (1978: 14-17) who summarized a series of findings in experimental game research by distinguishing between the 'given matrix' of objectively defined payoffs and an 'effective matrix' which in fact determines the strategy choices of the players.

The distinction rests on the recognition that actors act on the basis of subjective interpretations of reality, rather than on the basis of objectively given facts. By itself, of course, that truism would be theoretically unhelpful, substituting an unmanageable variety of cognitive and normative factors for the stark simplications of microeconomic theory. That trap is avoided by the proposition that the empirical variance of subjective interpretations of reality may be significantly reduced by specifying a limited number of ways in which relationship between the utilities of the parties may be perceived. They are expressed by transformation rules converting the payoffs of each player in the 'given matrix' into different sets of subjectively valued ${ }^{25}$ payoffs in the 'effective matrices'.

Three of these transformation rules seem to be included in most studies: the maximization of one's 'own gain', the maximization of one's 'relative gain' compared to the other party, and the maximization of the 'joint gains' of all parties (Messick and Thorngate, 1967; McClintock, 1972; Kelley and Thibaut, 1978: 140-50). While other rules are sometimes mentioned in the literature ${ }^{26}$ and while it may be possible to identify empirical or historical examples for all theoretically conceivable cases of a systematically complete

24. Rational-choice theorists have spent a good deal of effort trying to derive 'altruistic' or 'collective' or, at minimum, 'Kantian' preferences from 'individualistic' premises (Sen, 1977; Collard, 1978; Harsanyi, 1980; Kennett, 1980a; 1980b; Margolis, 1982; Kolm, 1983). It is probably fair to say that these efforts have led to a negative conclusion. Non-individualistic preferences are logically autonomous from, rather than derivatives of, individual egotism.

25. Transformation rules thus do not address the problem of perceptional distortions (Nisbet and Ross, 1980; Kahneman and Tversky, 1984). They continue to assume that the parties correctly perceive the objective payoffs of the given matrix.

26. McClintock as well as Kelley and Thibaut discuss an 'altruistic' (maximize other's gain) transformation, but assume that is of little practical significance. This is questionable when the role of judges or the need for trust in the altruism of professional helpers is considered (Barber, 1983). Kelley and Thibaut (1978: 145) also mention the possibility of an 'egalitarian' transformation (minimize relative gain) which might be relevant in socialist communities. But 
catalogue of transformation rules, these three are surely of the greatest practical importance in ordinary policy processes. Since they also happen to correspond directly to our three styles of decision-making, they will be the subject of the remaining discussion (figure 3). ${ }^{27}$

Figure 3. Individualistic, competitive and cooperative transformations of Battle of the Sexes

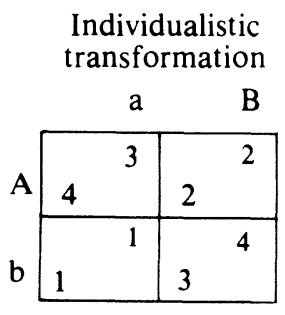

\section{Competitive transformation}

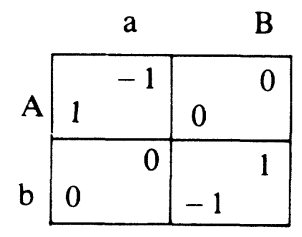

\author{
Cooperative \\ transformation
}

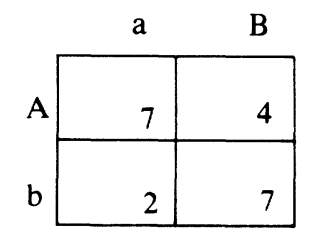

( = given matrix $)$

Under the first rule, 'own gain maximization', the given matrix is reproduced in identical form. The rule thus corresponds to the individualistic or utilitarian assumptions of microeconomics and conventional game theory, according to which actors not only have correct and complete information about the consequences of their choices, but are guided only by their own utility and are indifferent to the payoffs achieved by the other side. By the same token 'own gain maximization' provides a precise operational definition of the attitudes and behavioral tendencies associated above (p. 159) with the Bargaining style of decision-making. Since actors are assumed to be self-regarding and non-envious, Bargaining is conducive to the common search for compromises through which both parties are able to improve their

\section{(Note 26 continued)}

that does not seem to exhaust the potential range of human motives: ethnic and religious conflict often seems to imply a 'punitive' transformation (minimize other's gain), and some choices even also seem motivated by a desire for self-punishment. A complete typology might thus include the following transformations or logics of interaction': maximize/minimize own gain; maximize/minimize other's gain; maximize/minimize relative gain; maximize/minimize joint gains.

Of course, not all of these rules are empirically and historically equally likely to prevail (Hirschman, 1977). Nevertheless. I expect that the rational-choice approach will not be fully accepted in the social sciences unless it will transcend its exclusive focus on individualistic motives. Once the full range of human motivations is included, it is also likely that the conditions governing the shift from one logic of interaction to another will become theoretically more interesting than the further explication of specific logics.

27. In order to simplify the presentation, it is assumed that identical transformation rules will be applied by both parties. In real-world interactions, that is not necessarily the case. The dynamics of asymmetrical transformations are certainly important but cannot be explored here. 
position compared to the status quo.

This search for compromises is likely to lead to optimal outcomes in the Assurance, Chicken and Prisoner's Dilemma games. Even in Battle of the Sexes, the parties may be able to agree on the obvious compromise of turn-taking if the game is played repeatedly over identical stakes (Kelley and Thibaut, 1978: 101-2); and if outcomes are continuously variable, they may be able to 'split the difference' (Nash, 1950, 1953). Unfortunately, however, real-world negotiations must often deal with unique problems and 'lumpy' or qualitatively different solutions. When they correspond to the constellation of interests described by Battle of the Sexes, bargaining provides no criterion that would allow the parties to agree on the choice of one of the coordinated solutions $(\mathrm{A} / \mathrm{a}$ or $\mathrm{b} / \mathrm{B}){ }^{28}$

The second rule, 'relative gain maximization', represents a competitive transformation of the given matrix. The criterion now is winning or losing in comparison to the other player, rather than finding mutually agreeable compromises. The rule has excellent credentials in sociological and psychological theories of reference groups and of relative deprivation (Stouffer et al., 1949; Merton and Rossi, 1957; Runciman, 1966; Pettigrew, 1967)29 and it also agrees with the emphasis on competition in the socialization of individuals in Western culture (Deutsch, 1985). Examples that come to mind are competitive sports, electoral competition among political parties, or the arms race. Among our three styles of decision-making, the rule corresponds to the one we have labeled Confrontation. When it is applied to any one of the mixed motive games, the 'effective matrix' becomes zero-sum. Under Majority and Hierarchy, one side will be able to impose its preferred solution on the losers, but if the decision rule is Unanimity, neither party will voluntarily agree to the other's domination. In Battle of the Sexes, the players will then prefer the equality of non-coordination $(\mathrm{A} / \mathrm{B})$ to asymmetrical coordination (Aa or $\mathrm{bB}$ ), even though that outcome is objectively inferior to the one obtainable by voluntary submission.

The third rule, finally, implies a cooperative or 'solidaristic' transformation of the 'given matrix', so that 'an actor seeks those alternatives that afford both herself and the other the highest joint outcome' (McClintock, 1972: 447). If both parties apply the rule, the difference between their individual

28. The famous 'Nash solution' of normative bargaining theory eliminates the crucial element of 'Battle' - i.e. the need to choose between distinct and distributively different solutions - by assuming that outcomes are continuously variable (or can be made so through side payments or package deals). Where that is the case, outcomes will represent the respective bargaining power or threat positions of the players. That solution may be hard to identify in practice, and outcomes may depend much on the strategies and tactics of negotiation (Bacharach and Lawler, 1981; Fisher and Ury, 1983), but there is no reason to expect that the collective optimum will be systematically violated - as it is likely to be when 'Battle of the Sexes' is played over distinct and 'lumpy' outcomes.

29. Theories of relative deprivation could also suggest an 'egalitarian' transformation. minimizing, rather than maximizing relative gain. Under Unanimity, however, that would not alter the choice of outcomes. 
payoffs will become irrelevant, and they are both free to engage in a search for 'integrative' solutions (Walton and McKersie, 1965; Pruitt and Lewis, 1975) - which corresponds to our definition of the Problem-solving style of decision-making. Examples may be found among happy marriages, successful sports teams, solidaristic unions, or political parties during the honeymoon period of a new coalition government. Applied to Battle, the rule suggests that the players should be happy to accept either one of the coordinated solutions without regard to the question of distribution. ${ }^{30}$

What is important for our purposes is that both the competitive and the cooperative rules would transform Battle of the Sexes from a game without solution into one with predictable solutions. But these solutions differ significantly in their objective properties as these are defined by the 'given matrix'. Thus, if the parties will overcome their subjective interpretations and revert to an objective view of the real world (as they are likely to do now and then), they will discover that the outcomes achieved through Problem-solving are superior for either of them (but still different). Hence, if the transformation rule or interaction logic could be chosen at will, both players would be better off with a cooperative or Problem-solving view of their relationship. Yet the continuing conflict over distribution would probably frustrate any purely instrumental adoption of 'as-if' valuations.

What is psychologically more likely instead is an oscillation between competition and cooperation, or perhaps the cyclical changes of cooperative, individualistic and competitive attitudes which have been observed in long iterations of the non-cooperative Prisoner's Dilemma (Kelley and Thibaut, 1978: 231). In the case of Battle, one might thus expect that one of the parties, finding the search for advantageous solutions obstructed by disagreement in the Bargaining style, might turn to Problem-solving to improve their common welfare. But then her resentment over the unequal distribution of benefits could easily rise to the point where she will switch to Confrontation in order 'to get even' regardless of her own losses. Once that has happened, the relationship might break altogether, or (if exit is impossible) the experience of common misery might persuade both parties to begin a new round of Bargaining over mutually more attractive solutions.

\section{The Interaction of Decision Rules and Decision Styles}

But where does that leave us in our search for the parsimonious explanation

30. It is here that the disregard of the perceptual dimension may seriously impair the predictive value of the theory. Solidaristic communities, or 'sects' in the typology developed by Mary Douglas and Aaron Wildavsky (1982), are notorious for their internecine feuds rooted in cognitive differences that are interpreted as defection from the common goal. Thus, as a next step in theory development, propositions regarding rules and styles of decision-making need to be connected to propositions about commonalities and differences of belief systems or "cognitive maps' (Axelrod, 1976: Jönsson. 1983; Sabatier, 1987t that the collective optimum will be 
of policy choices? We have been able to identify three distinct socialpsychological mechanisms, corresponding to the decision styles of Bargaining, Confrontation and Problem-solving which influence the likelihood of socially superior or inferior policy choices quite independently from the applicable rules of decision. Of these, Confrontation will systematically lead to socially suboptimal outcomes. ${ }^{31}$ On the other hand, the most common and in many ways psychologically most robust Bargaining style (which would produce socially acceptable outcomes in Prisoner's Dilemma or Chicken games) is often likely to generate endless disagreement, blockades and socially suboptimal outcomes when the interest constellation resembles Battle of the Sexes. ${ }^{32}$ Problem-solving, finally, which would be the socially most desirable decision style, seems always threatened by an erosion of 'cooperative' or 'solidaristic' attitudes. The obvious next step is to explore more systematically the interaction effects between decision rules and decision styles (Figure 4). They are presented here in the form of two-by-three tables whose cells contain the game-theoretic solutions for the possible combinations of rules ${ }^{33}$ and styles in each of four archetypical games.

The upper row in each cell represents the outcome that is likely to be chosen in the (subjectively defined) 'effective matrix', and the numbers in the lower row represent the corresponding objective outcomes in the 'given matrix'. While the interpretation of some of the resulting patterns may be intuitively obvious, some are sufficiently interesting to merit further elaboration.

1. In all games, the same socially optimal outcomes are obtained whenever a Problem-solving style is assumed to govern policy choices (top row of cells). That is a reminder of the power of common orientations. Institutional arrangements make a difference if, and to the extent that, individuals who would otherwise pursue different or conflicting strategies need to be

\footnotetext{
31. This is not in conflict with the attribution of social benefits to market competition. First, economic theory presupposes 'individualistic', rather than 'competitive' motives in the sense used here. Second, 'social optimality' is a relative concept that must be defined by reference to a specific collectivity. In the text, it refers to the common interests of participants, rather than to the interests of a wider public. To illustrate the point, ideal markets define a Prisoner's Dilemma in which cartels (cooperation) would be 'socially optimal' for firms (prisoners) but not for the consumers represented by the cartel office (the sheriff).

32. The constellation may also have important cognitive implications. In games of pure coordination, in the mixed-motive Assurance Game, and in Prisoner's Dilemma and Chicken played as a cooperative game, the parties have a positive interest in improving the correctness of each other's views of the world in order to expedite agreement on a mutually agreeable solution. The same may also be true in zero-sum and mixed-motive constellations with a clear preponderance of power, where the 'winner' may have every interest in the prospective 'loser's' ability to correctly anticipate the likely outcome of a fight. Not so in a game without solution, like Battle, that is being played in a Bargaining spirit under the Unanimity rule: Here the parties may have a positive interest in inducing misperceptions that exaggerate their own, and underrepresent the other side's, alternative options. Hence the concern of negotiations research with the possibilities of tactical information and impression management (Raiffa, 1982; Fisher and Ury, 1981).

33. To simplify, I am only considering Unanimity and Hierarchy - defined as a situation in which a dominant player is able to determine the outcome for both parties. In this form of presentation, Majority would not differ from Hierarchy.
} 
Figure 4. The influence of decision rules and decision styles on outcomes ${ }^{\mathbf{a}}$ in four mixed-motive games

Decision rule

\begin{tabular}{|c|c|c|}
\hline Decision & Unanimity & ierarchy \\
\hline & (1) & (2) \\
\hline & 8 & 8 \\
\hline $\begin{array}{l}\text { Problem- } \\
\text { solving }\end{array}$ & --- & $4 / 4$ \\
\hline & (3) & (4) \\
\hline Bargaining & 4 / 4 & $\begin{array}{l}4 / 4 \\
-\ldots--\end{array}$ \\
\hline & $4 / 4$ & $4 / 4$ \\
\hline & (5) & I(6) \\
\hline & $0 / 0$ & $-2 / 2$ \\
\hline Confrontation & --.-- & ----- \\
\hline & $2 / 2$ & $1 / 3$ \\
\hline
\end{tabular}

Assurance
Decision rule

Unanimity Hierarchy

\begin{tabular}{|c|c|}
\hline \multicolumn{1}{|c|}{$(1)$} & \multicolumn{1}{|c|}{$(2)$} \\
$3 / 3$ & $3 / 3$ \\
\hline $3 / 3^{(3)}$ & $1 / 4^{(4)}$ \\
\hline $3 / 3$ & $1 / 4$ \\
\hline $0 / 0^{(5)}$ & $-3 / 3^{(6)}$ \\
\hdashline $2 / 2$ & $1 / 4$ \\
\hline
\end{tabular}

Prisoner's Dilemma

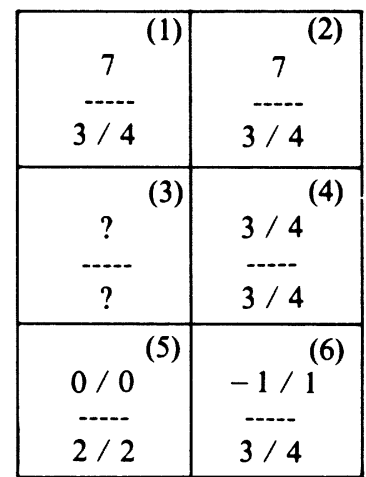

Battle of the Sexes

Chicken

\begin{tabular}{|c|c|}
\hline (1) & (2) \\
\hline 6 & 6 \\
\hline $3 / 3$ & $3 / 3$ \\
\hline (3) & (4) \\
\hline $3 / 3$ & $2 / 4$ \\
\hline $3 / 3$ & $2 / 4$ \\
\hline (5) & (6) \\
\hline $0 / 0$ & $-1 / 1$ \\
\hline---- & ..... \\
\hline $1 / 1$ & $2 / 4$ \\
\hline
\end{tabular}

${ }^{a}$ In each cell, the numbers above the dotted line represent the equilibrium outcome in the 'effective matrix'; those below the line represent the corresponding payoffs in the objectively 'given matrix'.

coordinated or constrained. By the same token, however, if solidaristic goals and common cognitive orientations can be generated and maintained among participants, decision rules, and institutional arrangements generally, have much less of an influence on policy choices. A good example is provided by the mobilization of union solidarity with an embattled Labour government during the 'social contract' period in Britain between the autumn of 1975 and 1977. In spite of a highly fragmented and decentralized industrial-relations system, British unions were then able to practise a voluntary form of incomes policy that was at least as effective in combatting wage inflation as was the 
wage restraint achieved by the much more concentrated and centralized Austrian, German and Swedish union organizations. ${ }^{34}$

Ironically, solidaristic ideology may account for both the presence and the absence of hierarchical power in organizations. The 'iron law of oligarchy' (Michels, 1915/1962) in traditional labor unions and socialist parties, for instance, is surely assisted by the assumption of common goals, delegitimating 'individualistic' concerns for the representation of member interests, or for the dangers inherent in hierarchical power. The same may be true of fundamentalist religious organizations. Conversely, solidaristic social movements may resist any form of formal organization in the belief that cooperation and coordination are assured by common goals and world views alone. Yet hierarchical power corrupts, 'individualistic' or 'competitive' self-interest is never exorcised permanently, and the world is too ambiguous to assure the continuing convergence of perceptions. Thus solidarity is a fragile condition, and is likely to need all the institutional help that it can get. More research on the conditions generating, maintaining and eroding the collectively beneficent decision style of Problem-solving is clearly needed.

2. If Problem-solving maximizes the production of collective welfare irrespective of decision rules, Confrontation is collectively suboptimal ${ }^{35}$ under almost all conditions (bottom row in all diagrams). But here, decision rules do make a difference: under Unanimity, Confrontation results in mutual blockage, so that opportunities for increasing total welfare through coordination remain unexploited. When the game resembles Chicken, the parties may even suffer jointly from carrying out their mutual threats. The equality which they in fact achieve is that of equal misery. When that is the case, Confrontation is unlikely to persist indefinitely, since both parties have an objective interest in exploring other decision styles.

Under Hierarchy, by contrast - i.e. when one side is able to dictate the solution - outcomes achieved in the confrontational style will be unequal. They are to the advantage of the dominant side in the Prisoner's Dilemma and in Chicken. But when objective interests are more harmonious, as they are in the Assurance Game, the confrontational pursuit of distributional advantages may perversely produce inferior outcomes even for the dominant party. On the other hand, if the game constellation resembles Battle of the Sexes, the maximization of distributional inequality by hierarchical domination (or by 'bloody-minded' majorities, for that matter) may even lead to outcomes which are objectively superior for the disadvantaged party compared to those which

34. But the British social contract collapsed in 1978, when union leaders were no longer able to maintain their solidaristic commitment against the pressures of intra- and inter-organizational competition. By contrast, countries with a greater degree of institutional concentration in their industrial relations found it much easier to maintain an economically optimal degree of wage restraint (Scharpf, 1987: 97-117, 212-51; 1988a).

35. Again it is necessary to keep in mind the system reference of such characterizations (see note 32). Thus it is entirely possible that Confrontation at one level (e.g. in collective bargaining) will facilitate solidaristic integration at the level below (e.g. within unions and employers associations). 
it could achieve under Unanimity. Under such conditions, the distributional inequality of outcomes may reinforce, rather than undermine, the prevailing confrontational decision style.

3. The social-psychologically most robust perception of self-interest is generally assumed to be 'individualistic'. When this Bargaining style is combined with the rule of Hierarchy, the outcomes are (subjectively and objectively) optimal for the dominant party. How well the weaker party will do under these circumstances depends entirely upon the character of the game: in Assurance, it will achieve its best possible payoff, in Battle its second-best result, and in the Prisoner's Dilemma its worst-case outcome. But if the decision rule is Unanimity, the outcomes achieved in a Bargaining spirit will be objectively optimal for both parties in all games except for Battle of the Sexes. In the Assurance Game, both will achieve all the benefits obtainable through Problem-solving without the need to generate and maintain solidaristic perspectives. Under conditions of Chicken or the Prisoner's Dilemma, furthermore, Bargaining under Unanimity will be able to protect the weaker party against extreme exploitation. This, surely, helps to explain the frequent resort to 'consociational' or 'Proporz' decision systems in countries with high levels of religious, ethnic, or class conflict (Lehmbruch, 1979).

However, as was pointed out above, consensual negotiations do not work well in Battle of the Sexes. Here individualistic Bargaining is likely to be difficult, and outcomes are unpredictable, under Unanimity, while Hierarchy would easily produce favorable outcomes even for the weaker party. The last proposition seems to correspond with the empirical finding that labor-dominated and capital-dominated political economies (while differing in their distributive outcomes) have done better in terms of economic growth, employment, and price stability during the crises of the 1970s and early 1980 s than countries where neither capital nor labor enjoyed a hegemonic preponderance (Schmidt, 1986, 1987).

Thus, the intersection of Unanimity and Bargaining in Battle of the Sexes merits further attention. If, as we have assumed, Battle represents a game constellation of great practical importance, if the domain of Unanimity is growing within the public sector as well as in interactions between the public and private spheres, and if Bargaining is the most robust or default style of decision-making ${ }^{36}$ - then we need more systematic knowledge about the potentially pathological policy implications of this particular constellation. ${ }^{37}$

36. The default character of Bargaining is reinforced by the predominance of 'utilitaristic' organizations, such as business firms, interest associations, or government bureaucracies, in real-world negotiation systems. The role definitions of their agents do not usually permit the solidaristic or confrontational redefinition of the interests at stake (which, however, may be achieved by the personal authority of leaders who are able to transcend their organizational roles).

37. No more than a beginning has been achieved in the analysis of the 'joint decision traps' created by de facto Unanimity in German federalism and in the European Community (Scharpf, $1988 c)$. 
Equally important is the search for mechanisms which might overcome the immobilism that is characteristic of policy-making in consensual negotiating systems. One promising field for exploration might be institutional arrangements that help to disentangle the contradictions and mutual interferences created by the simultaneous pursuit of common and conflicting interests. If decisions over the production of collective benefits could be procedurally separated from decisions over the distribution of benefits and costs, (as they are in some industrial-relations regimes), the parties might collaborate in successful 'productivity coalitions' without forcing one side or the other to generally accept an inferior distributive outcome (Scharpf, 1988b). A crucial ingredient in such procedural arrangements might be a basic understanding about rules of distributive justice and their spheres of application (Deutsch, 1985; Walzer, 1983).

\section{Conclusion}

Given the complexity of our subject, it is perhaps not surprising that more questions have been raised than answered. Nevertheless, the conceptualizations proposed here could open the way to developing a greater number of 'partial theories' of considerable relevance for the explanation of real-world policy choices. The constellations defined by the intersection of three dimensions of variables - type of game, decision rules and decision styles - are sufficiently specific to allow a considerable reduction of the contingency of choice situations. At the same time, the three dimensions are analytically transparent enough to permit the deductive development of well-understood theoretical models for each of the intersecting constellations. Given their greater complexity and specificity, these models will be able to explicate a larger portion of their contextual conditions (McGuire, 1983; Vayda, 1983; Greenwald et al., 1986), rather than submerge them in one inchoate ceteris paribus clause. Thus the empirical exploration, and perhaps even testing, of partial hypotheses should be greatly facilitated.

These hopes, of course, depend entirely upon our ability to operationalize and empirically identify the variables that have been specified theoretically. Presumably, that task is a feasible one for the definition of the decision rules which are in fact applied (Ostrom, 1988). But while a growing number of intuitively plausible studies have used game-theoretical concepts for the interpretation of real-world choice constellations, the methodology that would allow us to determine empirically, in a controlled way, what type of games are in fact being played, is still quite unclear. Even less is known about the empirical identification of decision styles whose underlying concepts have so far only been applied in carefully controlled social-psychological experimentation. So the task is set for a good deal of developmental effort before we can even hope to demonstrate the usefulness of the propositions suggested 
here for comparative policy research. But given the theoretical impasse of empirical policy research discussed in the introduction, an investment in more basic developmental work may nevertheless be our one best hope.

\section{Acknowledgement}

The article is based on work begun in 1987 while I was a fellow at the Center for Advanced Study in the Behavioral Sciences at Stamford. Helpful comments on earlier drafts by Jens Alber, Helena Flam, Jürgen Flick, Elinor Ostrom and Andreas Ryll are gratefully acknowledged.

\section{Bibliography}

Alford, Robert R. and Roger Friedland (1985) Powers of Theory. Capitalism, the State and Democracy. Cambridge: Cambridge University Press.

Axelrod, Robert (ed.) (1976) Structure of Decision: The Cognitive Maps of Political Elites. Princeton: Princeton University Press.

Bacharach, Samuel B. and Edward J. Lawler (1981) Bargaining: Power, Tactics, and Outcomes. San Francisco: Jossey-Bass.

Barber, Bernard (1983) The Logic and Limits of Trust. New Brunswick: Rutgers University Press.

Barnard, Chester I. (1947) The Functions of the Executive. Cambridge, MA: Harvard University Press.

Bickel, Alexander M. (1962) The Least Dangerous Branch: The Supreme Court at the Bar of Politics. Indianapolis: Bobbs-Merrill.

Blalock, Hubert M. (1961) Causal Inferences in Non-experimental Research. Chapel Hill: University of North Carolina Press.

Bonoma, Thomas V. (1976) 'Conflict, Cooperation and Trust in Three Power Systems', Behavioral Science 21: 499-513.

Braybrooke, David and Charles E. Lindblom (1963) A Strategy of Decision: Policy Evaluation as a Social Process. New York: Free Press.

Buchanan, James M. and Gordon Tullock (1962) The Calculus of Consent: Logical Foundations of Constitutional Democracy. Ann Arbor: University of Michigan Press.

Coase, Ronald (1960) 'The Problem of Social Cost', Journal of Law and Economics 3: $1-44$.

Coleman, James S. (1964) Introduction to Mathematical Sociology. New York: Free Press.

Coleman, James S. (1974) Power and the Structure of Society. New York: W.W. Norton.

Collard, David (1978) Altruism and Economy: A Study in Non-Selfish Economics. New York: Oxford University Press.

Dahl, Robert A. and Charles E. Lindblom (1953) Politics, Economics, and Welfare. Planning and Politico-Economic Systems Resolved into Basic Social Processes. New York: Harper and Row.

Deutsch, Morton (1985) Distributive Justice: A Social Psychological Perspective. New Haven: Yale University Press.

Dore, Ronald (1983) 'Goodwill and the Spirit of Market Capitalism', British Journal of Sociology XXXIV: $459-82$.

Douglas, Mary and Aaron Wildavsky (1982) Risk and Culture. Berkeley: University of California Press.

Elias, Norbert (1987) 'Wandlungen der Wir-Ich-Balance', in Norbert Elias, Die Gesellschaft der Individuen. Frankfurt: Suhrkamp.

Etzioni, Amitai (1961) A Comparative Analysis of Complex Organizations. New York: Free Press.

Feick, Jürgen and Werner Jann (1988) "“Nations Matter" - Vom Eklektizismus zur Integration in der vergleichenden Policyforschung?', Politische Vierteljahreschrift 29: 196-220. 


\section{DECISION RULES, DECISION STYLES AND POLICY CHOICES}

Fisher, Roger and William Ury (1983) Getting to Yes: Negotiating Agreement without Giving In. Harmondsworth: Penguin.

Follett, Mary Parker (1941) 'Constructive Conflict', pp. 30-49 in Henry C. Metcalf and L. Urwick (eds), Dynamic Administration: The Collected Papers of Mary Parker Follett. New York: Harper.

Garlichs, Dietrich (1980) Grenzen staatlicher Infrastrukturpolitik: Bund/Länder-Kooperation in der Fernstrassenplanung. Königstein/Ts: Anton Hain.

Glaser, Barney G. and Anselm L. Strauss (1967) The Discovery of Grounded Theory: Strategies for Qualitative Research. Chicago: Aldine Atherton.

Greenwald, Anthony, Anthony A. Pratkanis, Michael R. Leippe and Michael H. Baumgardner (1986) 'Under What Conditions Does Theory Obstruct Research Progress?', Psychological Review 93: 216-29.

Hamburger, Henry (1979) Games as Models of Social Phenomena. San Francisco: Freeman.

Hardin, Russell (1982) Collective Action. Baltimore: Johns Hopkins University Press.

Harsanyi. John C. (1980) 'Rule Utilitarianism, Rights, Obligations and the Theory of Rational Behavior', Theory and Decision 12: 115-33.

Hirschman, Albert O. (1977) The Passions and the Interests: Political Arguments for Capitalism before its Triumph. Princeton: Princeton University Press.

John, Robert (1980) 'Theory Construction in Sociology: The Competing Approaches', MidAmerican Review of Sociology 5: 15-36.

Jönsson, Christer (1983) 'A Cognitive Approach to International Negotiation', European Journal of Political Research 11: 139-50.

Kahneman, Daniel and Amos Tversky (1984) 'Choices, Values, and Frames', American Psychologist 39: 341-50.

Kaufmann, Franz-Xaver, Giandomenico Majone and Vincent Ostrom (eds) (1986) Guidance, Control, and Evaluation in the Public Sector: The Bielefeld Interdisciplinary Project. Berlin: de Gruyter.

Kelley, Harold H. and John W. Thibaut (1978) Interpersonal Relations: A Theory of Interdependence. New York: John Wiley.

Kennett, David A. (1980a) 'Altruism and Economic Behavior, I: Developments in the Theory of Public and Private Redistribution', American Journal of Economics and Sociology 39: 183-98.

Kennett, David A. (1980b) 'Altruism and Economic Behavior: II. Private Charity and Public Policy', American Journal of Economics and Sociology 39: 337-54.

Kolm, Serge-Christophe (1983) 'Altruism and Efficiency', Ethics 94: 18-65.

Latsis, Spiros (1972) 'Situational Determinism in Economics', British Journal for the Philosophy of Science 23: $207-45$.

Layder, Derek (1982) 'Grounded Theory: A Constructive Critique', Journal for the Theory of Social Behavior 12: 103-23.

Lehmbruch, Gerhard (1967) Proporzdemokratie: Politisches System und politische Kultur in der Schweiz und Österreich. Tübingen: Mohr.

Lehmbruch, Gerhard (1968) 'Konkordanzdemokratie im politischen System der Schweiz', Politische Vierteljahresschrift 9: 443-59.

Lehmbruch, Gerhard (1976) Parteienwettbewerb im Bundesstaat. Stuttgart: Kohlhammer.

Lehmbruch, Gerhard (1979) 'Consociational Democracy, Class Conflict and the New Corporatism', in Philippe C. Schmitter and Gerhard Lehmbruch (eds) Trends Towards Corporatist Intermediation, pp. 53-62. London: Sage.

Lijphart, Arendt (1969) 'Consociational Democracy', World Politics 21: 207-25.

Lowi, Theodore (1964) 'American Business, Public Policy, Case Studies and Political Theory', World Politics 16: 677-715.

Luce, R. Duncan and Howard Raiffa (1957) Games and Decisions. Introduction and Critical Survey. New York: John Wiley.

McClintock, Charles G. (1972) 'Social Motivation - A Set of Propositions', Behavioral Science 17: 438-54.

McGuire, William J. (1983) A Contextualist Theory of Knowledge: Its Implications for Innovation and Reform in Psychological Research', in Leonard Berkowitz (ed.) Advances in Experimental Social Psychology, Vol. 16, pp. 1-47. Orlando, FL: Academic Press. 
Macneil, Ian R. (1978) 'Contracts: Adjustment of Long-term Economic Relations Under Classical, Neoclassical, and Relational Contract Law', Northwestern University Law Review 72: 854-905.

Macneil, Ian R. (1983) 'Values in Contract: Internal and External', Northwestern University Law Review 78: $340-418$.

Macneil, Ian R. (1987) 'Political Exchange as Relational Contract', MS, European University Institute, Florence.

March, James G. and Herbert A. Simon (1958) Organizations. New York: John Wiley.

Margolis, Howard (1982) Selfishness, Altruism, and Rationality. A Theory of Social Choice. Cambridge: Cambridge University Press.

Mayntz, Renate and Fritz W. Scharpf (1975) Policy-Making in the German Federal Bureaucracy. Amsterdam: Elsevier.

Mayntz, Renate, H.-U. Derlien, E. Bohne, B. Hesse, J. Hucke and A. Müller (1978) Vollzugsprobleme der Umweltpolitik - Empirische Untersuchung der Implementation von Gesetzen im Bereich der Luftreinhaltung und des Gewässerschutzes. Materialien zur Umweltforschung, Rat von Sachverständigen für Umweltfragen (ed.). Stuttgart: Kohlhammer.

Mayntz, Renate and Birgitta Nedelmann (1987) 'Eigendynamische soziale Prozesse. Anmerkungen zu einem analytischen Paradigma', Kölner Zeitschrift für Soziologie und Sozialpsychologie 39: 648-68.

Merton, Robert K. and Alice S. Rossi (1957) 'Contributions to the Theory of Reference Group Behavior', in R.K. Merton Social Theory and Social Structure (rev. ed.). Glencoe, IL: Free Press.

Messick, David M. and Warren B. Thorngate (1967) 'Relative Gain Maximization in Experimental Games', Journal of Experimental Social Psychology 3: 85-101.

Michels, Roberto (1915/1962) Political Parties. New York: Collier Books.

Midgaard, Knut (1983) 'Rules and Strategy in Negotiations: Notes on an Institutionalist and Intentionalist Approach', European Journal for Political Research 11: 151-66.

Mueller, Dennis C. (1979) Public Choice. Cambridge: Cambridge University Press.

Nash, John F. (1950) 'The Bargaining Problem', Econometrica 18: 155-62.

Nash, John F. (1953) 'Two-Person Cooperative Games', Econometrica 21: 128-40.

Neumann, John von and Oskar Morgenstern (1944) Theory of Games and Economic Behavior. Princeton: Princeton University Press.

Nisbett, Richard and Lee Ross (1980) Human Inference: Strategies and Shortcomings of Social Judgment. Englewood Cliffs: Prentice-Hall.

Olsen, Johan, Paul Roness and Harald Saetren (1982) 'Norway: Still Peaceful Coexistence and Revolution in Slow Motion', in Jeremy Richardson (ed.) Policy Styles in Western Europe, pp. 47-79. London: George Allen and Unwin.

Olson, Mancur (1982) The Rise and Decline of Nations. Economic Growth, Stagflation, and Social Rigidities. New Haven: Yale University Press.

Ostrom, Elinor (1986a) 'A Method of Institutional Analysis', pp. 459-75 in Kaufmann, Majone and Ostrom (eds).

Ostrom Elinor (1986b) 'An Agenda for the Study of Institutions', Public Choice 48: 3-25.

Ostrom Elinor (1988) 'The Commons and Collective Action', MS, Workshop in Political Theory and Policy Analysis, Indiana University.

Ouchi, William G. (1980) 'Markets, Bureaucracies and Clans', Administrative Science Quarterly 25: $129-41$.

Ouchi, William G. (1984) The M-Form Society: How American Teamwork Can Recapture the Competitive Edge. Reading, MA: Addison-Wesley.

Pettigrew, Thomas E. (1967) 'Social Evaluation Theory: Convergences and Applications', in David Levine (ed.) Nebraska Symposium on Motivation, pp. 241-315. Lincoln: University of Nebraska Press.

Piore, Michael J. and Charles F. Sabel (1984) The Second Industrial Divide. Possibilities for Prosperity. New York: Basic Books.

Posse, Achim Ulrich (1986) Föderative Politikverflechtung in der Umweltpolitik. Munich: Minerva-Publikation (Innenpolitik in Theorie und Praxis 16).

Powell, Walter W. (1987) 'Neither Market Nor Hierarchy: The Limits of Organization', MS, Stanford, CASBS, June 1987. 


\section{DECISION RULES, DECISION STYLES AND POLICY CHOICES}

Pruitt, Dean G. and Steven A. Lewis (1975) 'Development of Integrative Solutions in Bilateral Negotiation', Journal of Personality and Social Psychology 31: 621-33.

Przeworski, Adam and Henry Teune (1970) The Logic of Comparative Social Inquiry. New York: John Wiley.

Raiffa, Howard (1982) The Art and Science of Negotiation. Cambridge, MA: Harvard University Press.

Reh, Werner (1986) Politikverflechtung im Fernstrassenbau der Bundesrepublik Deutschland und im Nationalstrassenbau der Schweiz: Eine vergleichende Untersuchung zur Effizienz und Legitimation des bürokratischen Föderalismus. $\mathrm{PhD}$ dissertation, University of Mannheim.

Runciman, W.G. (1966) Relative Deprivation and Social Justice: A Study of Attitudes to Social Inequality in Twentieth-Century England. Berkeley: University of California Press.

Sabatier, Paul A. (1987) 'Knowledge, Policy-Oriented Learning, and Policy Change', Knowledge: Creation, Diffusion, Utilization 8: 649-92.

Sabel, Charles F. (1987) 'The Reemergence of Regional Economies: Changes in the Scale of Production', MS, Massachusetts Institute of Technology.

Scharpf, Fritz W. (1972) 'Komplexität als Schranke der politischen Planung', Politische Vierteljahresschrift 13, Sonderheft 4: 168-92.

Scharpf, Fritz W. (1987) Sozialdemokratische Krisenpolitik in Europa. Frankfurt: Campus.

Scharpf, Fritz W. (1988a) 'A Game-Theoretical Interpretation of Inflation and Unemployment in Western Europe', Journal of Public Policy 7: 227-57.

Scharpf, Fritz W. (1988b) 'Verhandlungssysteme, Verteilungskonflikte und Pathologien der politischen Steuerung', in Manfred G. Schmidt (ed.) Staatstätigkeit: International vergleichende Analysen, pp. 61-87. Politische Vierteljahresschrift, Sonderheft 19.

Scharpf, Fritz W. (1988c) 'The Joint Decision Trap', Public Administration 66: 239-78.

Scharpf, Fritz W., Bernd Reissert and Fritz Schnabel (1978) 'Policy Effectiveness and Conflict Avoidance in Intergovernmental Policy Formation', in Kenneth Hanf and Fritz W. Scharpf (eds) Interorganizational Policy Making. Limits to Coordination and Central Control, pp. 57-112. London: Sage.

Schmidt, Manfred G. (1986) 'Politische Bedingungen erfolgreicher Wirtschaftspolitik - eine vergleichende Analyse westlicher Industrieländer', Journal für Sozialforschung 26: 251-73.

Schmidt, Manfred G. (1987) 'The Politics of Labour Market Policy: Structural and Political Determinants of Full Employment and Mass Unemployment in Mixed Economies', in Francis G. Castles, Franz Lehner and Manfred G. Schmidt (eds) Managing Mixed Economies, pp. 4-63. Berlin: De Gruyter.

Schmitter, Philippe C. (1979) 'Still the Century of Corporatism?', in Philippe C. Schmitter and Gerhard Lehmbruch (eds) Trends Toward Corporatist Intermediation, pp. 7-52. London: Sage.

Schmitter, Philippe C. (1981) 'Interest Intermediation and Regime Governability in Contemporary Western Europe and North America', in Suzanne Berger (ed.) Organizing Interests in Western Europe: Pluralism, Corporatism, and the Transformation of Politics, pp. 285-327. Cambridge: Cambridge University Press.

Sen, Amartya K. (1969) 'A Game-Theoretic Analysis of Theories of Collectivism in Allocation', in Tapas Majumdar (ed.) Growth and Choice, pp. 1-17. Oxford: Oxford University Press.

Sen, Amartya K. (1977) 'Rational Fools: A Critique of the Behavioral Foundations of Economic Theory', Philosophy and Public Affairs 6: 317-44.

Shepsle, Kenneth A. and Barry R. Weingast (1981) 'Political Preferences for the Pork Barrel: A Generalization', American Journal of Political Science 25: 96-111.

Simon, Herbert A. (1957) Administrative Behavior. A Study of Decision-Making Processes in Administrative Organization (2nd ed.) New York: Free Press.

Snidal, Duncan (1985) 'Coordination versus Prisoner's Dilemma: Implications for International Cooperation and Regimes', American Political Science Review 79: 923-42.

Stinchcombe, Arthur L. (1985) 'Contracts as Hierarchical Documents', in Arthur L. Stinchcombe and Carol A. Heimer Organization Theory and Project Management. Administering Uncertainty in Norwegian Offshore Oil, pp. 121-71. Oslo: Norwegian University Press.

Stone, Harlan Fisk (1936) 'The Common Law in the United States', Harvard Law Review 50: $4-26$. 
Stouffer, Samuel A., et al. (1949) The American Soldier, I: Adjustment during Army Life. Princeton: Princeton University Press.

Thompson, James D. (1970) 'Comment: Power as Energy or Power as a Reflection of Things', in Mayer N. Zald (ed.) Power in Organizations, pp. 90-92. Nashville, TN: Vanderbilt University Press.

Tsebelis, George (1988) 'Nested Games: The Cohesion of French Electoral Coalitions', British Journal of Political Science 18: 145-70.

Vayda, Andrew P. (1983) 'Progressive Contextualization: Methods for Research in Human Ecology', Human Ecology 11: 265-81.

Walton, Richard E. and Robert B. McKersie (1965) A Behavioral Theory of Labor Negotiations: An Analysis of a Social Interaction System. New York: McGraw-Hill.

Walzer, Michael (1983) Spheres of Justice. A Defense of Pluralism and Equality. New York: Basic Books.

Weingast, Barry R. (1979) 'A Rational Choice Perspective on Congressional Norms', American Journal of Political Science 23: 245-63.

Wiesenthal, Helmut (1987) 'Akteurrationalität. Überlegungen zur Steuerungsfähigkeit politischer Akteure in der Beschäftigungskrise', MS, University of Bielefeld, Faculty of Sociology.

Willer, David (1978) 'What is Exact Theory?', in Robert Smith and Bo Anderson (eds) Theory Development. New York: Halstedt Press.

Williamson, Oliver E. (1975) Markets and Hierarchies: Analysis and Antitrust Implications. New York: Free Press.

Williamson, Oliver E. (1979) 'Transaction-Cost Economics: The Governance of Contractual Relations', Journal of Law and Economics 22: 233-61.

Williamson, Oliver E. (1985) The Economic Institutions of Capitalism: Firms, Markets, Relational Contracting. New York: Free Press.

Zintl, Reinhard (1987) 'Der homo oeconomicus als Generalist oder als Spezialist? Über die Verwendung rationalistischer Rekonstruktionen der Mikroebene', MS, Universität der Bundeswehr, Munich.

FRITZ W. SCHARPF was formerly Professor of Political Science at the University of Konstanz and Director of the International Institute of Management, at the Wissenschaftszentrum, Berlin. Since 1986 he has been Director at the Max-Planck-Institut für Gesellschaftsforschung in Cologne. ADDRESS: 2 Max-Planck Institut für Gesellschaftforschung, 78 Lothringer Strasse, Cologne D-5000, FR Germany.

Paper submitted 11 May 1988; accepted for publication 27 August 1988. 